\title{
The effect of an essential oil combination derived from selected herbs growing wild in Turkey on broiler performance
}

\author{
A. Alçiçek ${ }^{1 \#}$, M. Bozkurt ${ }^{2}$ and M. Çabuk ${ }^{3}$ \\ ${ }^{1}$ Department of Animal Science, Agricultural Faculty of Ege University, Bornova 35100, Izmir-Turkey \\ ${ }^{2}$ Poultry Research Institute, Erbeyli 09600, Aydın-Turkey \\ ${ }^{3}$ Department of Poultry Science, Vocational School of Celal Bayar University, Akhisar 45210, Manisa-Turkey
}

\begin{abstract}
One thousand two hundred and fifty sexed day-old broiler chicks obtained from a commercial hatchery were divided randomly into five treatment groups (negative control, antibiotic and essential oil combination (EOC) at three levels) of 250 birds each. Each treatment group was further sub-divided into five replicates of 50 birds ( 25 male and 25 female) per replicate. The oil in the EOC was extracted from different herbs growing in Turkey. The EOC at 24,48 or $72 \mathrm{mg} / \mathrm{kg}$ diet and an antibiotic at $10 \mathrm{mg}$ avilamycin $/ \mathrm{kg}$ diet were added to the basal diet. There were significant effects of dietary treatments on body weight, feed intake (except at day 42), feed conversion ratio and carcass yield at 21 and 42 days. Body weights were significantly different between the treatments. The birds fed the diet containing $48 \mathrm{mg}$ essential oil $/ \mathrm{kg}$ were the highest, followed by those receiving the diets containing $72 \mathrm{mg}$ essential oil $/ \mathrm{kg}$, the antibiotic, the negative control and the $24 \mathrm{mg}$ essential oil/kg at day 42, respectively. From 1 to 21 and 1 to 42 days of age, feed conversion ratios were improved significantly by the supplementation with 48 and $72 \mathrm{mg}$ essential oil $/ \mathrm{kg}$ diet. The feed intakes were significantly different between the treatments at 21 days, but not at 42 days. Supplementation in excess of $48 \mathrm{mg}$ EOC $/ \mathrm{kg}$ had no additional beneficial effect on body weight, feed intake, feed conversion ratio and carcass yield. The EOC, a feed additive of natural origin, may be considered as a potential growth promoter in broiler production.
\end{abstract}

Keywords: Essential oil combination, herbs, antibiotic, performance, broiler

${ }^{\#}$ Corresponding author. E-mail: alcicek@ziraat.ege.edu.tr

\section{Introduction}

Broilers today grow much faster and reach higher market weights than ever before, not only because of the feed formulation which has had to keep up with genetic improvement, but also through improved management practices. Furthermore, growth promoting substances are assuming a position of prime importance in poultry. They are aimed primarily at the improving of the physical performance of poultry such as increasing body weight gains and improved feed conversion ratios in broiler production. Antibiotics have been used as growth promoting substance. However, the using of antibiotics as feed additives is risky due to, not only cross-resistance, but also to multiple resistance in pathogens (Bach Knudsen, 2001; Schwarz et al., 2001). Therefore, antibiotics have been discredited by consumer associations as well as by scientists, e.g. the use of most antibiotic growth promoters has been banned by the European Union (EU). Consequently, the animal feed industry is under increasing consumer pressure to reduce the use of antibiotics as a feed additive and find substitutes for antibiotics in the diet (Hertrampf, 2001; Humphrey et al., 2002). Many scientists have searched for alternatives to antibiotics (Langhout, 2000; Mellor, 2000; Wenk, 2000; Kamel, 2001). A number of scientific studies has concentrated on the bactericidal and bacteriostatic aspects of various plants and plant extracts (Riebau et al., 1995; Riebau et al., 1997; Marino et al., 1999). In 1943, Osborn reported more than 60 genera of plants that exhibit inhibitory properties toward the growth of either Escherichia coli or Staphylococcus aureus or both. Essential oils derived mainly from spices and herbs and their purified compounds have been shown to have antimicrobial actions in vitro (Cowan, 1999; Ultee et al., 2002; Faleiro et al., 2003). Examples of such natural antimicrobial compounds are carvacrol, tymol, limonene and cineole that are present in the essential oil fractions of oregano, laurel, sage and myrtle (Riebau et al., 1997; Ultee et al., 2002). Essential oils are commercially available and are used extensively in medicine and in the food and cosmetic industries. In addition to their antimicrobial activity, they possess biological activities such as that of antioxidants (Lopez-Bote et al., 1998; Botsoglou et al., 2002) and as hypocholesterolemics (Craig, 1999). Moreover, scientists recently discovered that essential oils have a stimulating effect on animal digestive systems. They postulated that these effects could be due to the 
increased production of digestive enzymes and the improved utilization of digestive products through enhanced liver functions (Langhout, 2000; Williams \& Losa, 2001). Therefore, specific essential oils and combinations of them provide a totally new approach to improving feed digestion. The use of essential oils in animal production may, therefore, have a promising potential as growth promoters without the adverse effects of antibiotics. However, the value of these oils in poultry production has not yet been well investigated.

This experiment was conducted to determine the effects of the dietary supplementation of essential oil combinations (EOC) derived from herbs growing wild in Turkey on the performance of broilers.

\section{Materials and Methods}

Table 1 Ingredient and chemical composition of the experimental starter and finisher diets (as fed)

\begin{tabular}{|c|c|c|c|c|c|c|c|c|c|c|}
\hline \multirow[b]{3}{*}{ Ingredients (kg/1000 kg) } & \multicolumn{10}{|c|}{ Treatment } \\
\hline & \multicolumn{5}{|c|}{1 to 21 days } & \multicolumn{5}{|c|}{22 to 42 days } \\
\hline & Diet 1 & Diet 2 & Diet 3 & Diet 4 & Diet 5 & Diet 1 & Diet 2 & Diet 3 & Diet 4 & Diet 5 \\
\hline Maize & 459.0 & 459.2 & 459.2 & 459.2 & 459.2 & 632.5 & 632.8 & 632.8 & 632.8 & 632.8 \\
\hline Soyabean meal (0.48 CP) & 277.8 & 278.4 & 278.4 & 278.4 & 278.4 & 230.0 & 230.0 & 230.0 & 230.0 & 230.0 \\
\hline Wheat & 100 & 100 & 100 & 100 & 100 & 0 & 0 & 0 & 0 & 0 \\
\hline Sunflower meal & 54.8 & 52.3 & 52.3 & 52.3 & 52.3 & 11.6 & 9.5 & 9.5 & 9.5 & 9.5 \\
\hline Meat and bone meal & 0 & 0 & 0 & 0 & 0 & 30 & 30 & 30 & 30 & 30 \\
\hline Fish meal & 34.5 & 35.2 & 35.2 & 35.2 & 35.2 & 38.0 & 38.9 & 38.9 & 38.9 & 38.9 \\
\hline Vegetable oil & 40 & 40 & 40 & 40 & 40 & 40 & 40 & 40 & 40 & 40 \\
\hline Salt & 2.5 & 2.5 & 2.5 & 2.5 & 2.5 & 2.5 & 2.5 & 2.5 & 2.5 & 2.5 \\
\hline Ground limestone & 15.9 & 15.9 & 15.9 & 15.9 & 15.9 & 9.9 & 9.8 & 9.8 & 9.8 & 9.8 \\
\hline Dicalcium phosphate & 10 & 10 & 10 & 10 & 10 & 0 & 0 & 0 & 0 & 0 \\
\hline Vitamin premix* & 2.5 & 2.5 & 2.5 & 2.5 & 2.5 & 2.5 & 2.5 & 2.5 & 2.5 & 2.5 \\
\hline Mineral premix $* *$ & 1 & 1 & 1 & 1 & 1 & 1 & 1 & 1 & 1 & 1 \\
\hline DL-methionine & 1 & 1 & 1 & 1 & 1 & 1 & 1 & 1 & 1 & 1 \\
\hline L-lysine & 1 & 1 & 1 & 1 & 1 & 1 & 1 & 1 & 1 & 1 \\
\hline Antibiotic premix & - & 1 & - & - & - & - & 1 & - & - & - \\
\hline EOC $(24 \mathrm{~g} / \mathrm{kg})$ premix & - & - & 1 & - & - & - & - & 1 & - & - \\
\hline EOC $(48 \mathrm{~g} / \mathrm{kg})$ premix & - & - & - & 1 & - & - & - & - & 1 & - \\
\hline EOC $(72 \mathrm{~g} / \mathrm{kg})$ premix & - & - & - & - & 1 & - & - & - & - & 1 \\
\hline Total & 1000 & 1000 & 1000 & 1000 & 1000 & 1000 & 1000 & 1000 & 1000 & 1000 \\
\hline \multicolumn{11}{|c|}{ Composition, g/kg (analysed) } \\
\hline Dry matter & 916 & 922 & 927 & 929 & 928 & 930 & 932 & 940 & 937 & 933 \\
\hline Crude protein $(\mathrm{CP})$ & 214 & 212 & 216 & 217 & 212 & 192 & 195 & 190 & 195 & 192 \\
\hline Crude fat & 44.5 & 46.6 & 46.0 & 48.3 & 46.1 & 56.8 & 59.5 & 58.0 & 56.2 & 60.3 \\
\hline Crude fibre & 45.5 & 40.5 & 42.3 & 39.2 & 40.8 & 34.5 & 31.0 & 33.0 & 35.5 & 31.7 \\
\hline Crude ash & 62.5 & 61.2 & 59.5 & 67.0 & 67.6 & 55.5 & 56.0 & 62.0 & 64.5 & 58.3 \\
\hline Starch & 400 & 397 & 393 & 391 & 400 & 413 & 419 & 430 & 419 & 424 \\
\hline Sugar & 44.8 & 49.0 & 53.2 & 56.4 & 52.5 & 48.1 & 53.8 & 48.1 & 53.1 & 48.6 \\
\hline Total calcium & 12.0 & 11.2 & 12.4 & 12.5 & 11.3 & 12.0 & 10.0 & 11.4 & 11.0 & 10.5 \\
\hline Total phosphorus & 5.5 & 5.5 & 5.5 & 5.9 & 6.0 & 4.6 & 5.0 & 4.9 & 5.1 & 5.1 \\
\hline Lysine (calculated) & 12.5 & 12.5 & 12.5 & 12.5 & 12.5 & 11.6 & 11.6 & 11.6 & 11.6 & 11.6 \\
\hline Met. + Cys. (calculated) & 8.3 & 8.3 & 8.3 & 8.3 & 8.3 & 7.6 & 7.6 & 7.6 & 7.6 & 7.6 \\
\hline $\mathrm{ME}(\mathrm{MJ} / \mathrm{kg})$ & 13.0 & 13.0 & 13.1 & 13.2 & 13.1 & 13.3 & 13.6 & 13.6 & 13.5 & 13.7 \\
\hline
\end{tabular}

EOC - Essential oil combination; ME - Metabolisable energy

Diet 1: Negative control: without antibiotic and EOC

Diet 2: with antibiotic, $10 \mathrm{mg}$ avilamycin $/ \mathrm{kg}$ diet

Diet 3, 4 and 5: with 24, 48 and $72 \mathrm{mg}$ EOC/kg diet, respectively

*Vitamin premix (/kg diet): vitamin A, $12000 \mathrm{IU}$; vitamin $\mathrm{D}_{3}, 1500 \mathrm{IU}$; vitamin $\mathrm{E}, 30 \mathrm{mg}$; vitamin $\mathrm{K}_{3}$, $5 \mathrm{mg}$; vitamin $\mathrm{B}_{1}, 3 \mathrm{mg}$; vitamin $\mathrm{B}_{2}, 6 \mathrm{mg}$; vitamin $\mathrm{B}_{6}, 5 \mathrm{mg}$; vitamin $\mathrm{B}_{12}, 0.03 \mathrm{mg}$; nicotine amide, $40 \mathrm{mg}$; calcium-D-pantothenate, $10 \mathrm{mg}$; folic acid, $0.75 \mathrm{mg}$; D-biotin, $0.075 \mathrm{mg}$; choline chloride, $375 \mathrm{mg}$; antioxidant, $10 \mathrm{mg}$

**Mineral combination (mg/kg diet): $\mathrm{Mn}, 80 ; \mathrm{Fe}, 80 ; \mathrm{Zn}, 60 ; \mathrm{Cu}, 8 ; \mathrm{I}, 0.5 ; \mathrm{Co}, 0.2 ; \mathrm{Se}, 0.15$ 
One thousand two hundred and fifty sexed day-old broiler chicks obtained from a commercial hatchery were divided into five treatment groups of 250 birds each and randomly assigned to the five treatment diets. Each treatment group was further sub-divided into five replicates of 50 birds (25 male and 25 female) per replicate. In the negative control treatment the birds were fed a standard commercial starter diet from days 1 to 21 and a grower diet from days 22 to 42 . An antibiotic or three different levels of an EOC were added to the standard diets to form the other four treatments. The antibiotic and the EOC were mixed in a carrier, which was then added at one $\mathrm{kg}$ per ton to the basal diet. In the antibiotic treatment a $\mathrm{kg}$ of feed contained $10 \mathrm{mg}$ of the antibiotic, avilamycin. For the EOC treatments, 24,48 or $72 \mathrm{mg}$ of a commercial EOC (Herbromix ${ }^{\mathrm{TM}}$ ) were added per $\mathrm{kg}$ of feed. The EOC contained six different essential oils, derived from selected herbs growing wild in Turkey, viz. oregano oil (Origanum sp.), laurel leaf oil (Laurus nobilis L.), sage leaf oil (Salvia triloba L.), myrtle leaf oil (Myrtus communis), fennel seeds oil (Foeniculum vulgare) and citrus peel oil (Citrus sp.). Hydrodistillation was used to extract the essential oils.

The ingredient and chemical composition of the diets are presented in Table 1. The diets were isoenergetic and isonitrogenous. The experimental diet in mash form and water were provided ad libitum for the duration of the trial. The birds were kept in 25 pens $(3 \times 1.7 \mathrm{~m})$ in an open-sided naturally ventilated broiler house containing wood shavings as litter material. Bird density was 10 chicks per square meter. A photoperiod of $24 \mathrm{~h} / \mathrm{d}$ was maintained. The body weights of the birds were measured individually and feed intakes per pen were recorded. Feed conversions were calculated at the end of the 21- and the 42-day experimental periods. Mortality was recorded daily and used to adjust the total number of birds to determine the total feed intake per bird. At 42 days, 12 male and 12 female birds of similar body weight were selected from each treatment group, weighed and killed by $\mathrm{CO}_{2}$ asphyxiation to determine carcass yields.

The standard techniques of the Proximate analysis were used to determine the nutrient concentrations in the diets (Naumann \& Bassler, 1993). The experimental diets were analysed also for starch, sugar, total calcium and phosphorus, according to VDLUFA method (Naumann \& Bassler, 1993). Metabolisable energy content of the diets was calculated based on chemical composition (Anonymous, 1991). The data were analysed using the General Linear Models procedure of SAS (1985). Significant differences between treatment means were separated using the Duncan's multiple range test with a 5\% probability.

\section{Results and Discussion}

Table 2 The effect of the inclusion of an essential oil combination (EOC) or an antibiotic (avilamycin) on feed intake (as fed) and the feed conversion ratio ( $\mathrm{g}$ feed/g gain) of broilers up to the age of 42 days

\begin{tabular}{ccccc}
\hline \multirow{2}{*}{ Treatments } & \multicolumn{2}{c}{$\begin{array}{c}\text { Feed intake } \\
\text { g }\end{array}$} & \multicolumn{2}{c}{$\begin{array}{c}\text { Feed conversion ratio } \\
\text { g feed/g gain }\end{array}$} \\
\cline { 2 - 5 } Control & 21 days* $^{\mathrm{ab}}$ & 42 days & 21 days* & 42 days* \\
\cline { 2 - 5 } $10 \mathrm{mg}$ avilamycin/kg & $979^{\mathrm{abc}}$ & 3756 & $1.87^{\mathrm{ab}}$ & $2.27^{\mathrm{ab}}$ \\
$24 \mathrm{mg} \mathrm{EOC} / \mathrm{kg}$ & $998^{\mathrm{a}}$ & 3792 & $1.94^{\mathrm{a}}$ & $2.19^{\mathrm{b}}$ \\
$48 \mathrm{mg} \mathrm{EOC/kg}$ & $964^{\mathrm{cd}}$ & 3683 & $1.75^{\mathrm{bc}}$ & $2.23^{\mathrm{ab}}$ \\
$72 \mathrm{mg}$ EOC/kg & $949^{\mathrm{de}}$ & 3771 & $1.67^{\mathrm{c}}$ & $1.99^{\mathrm{c}}$ \\
Standard error & $932^{\mathrm{e}}$ & 3675 & $1.65^{\mathrm{c}}$ & $2.06^{\mathrm{c}}$ \\
$\mathrm{P}$ & 9.93 & 40.68 & 0.05 & 0.04 \\
\hline
\end{tabular}

*Means within columns with different superscripts differ at $\mathrm{P}<0.01$

The effects of dietary EOC and the antibiotic on the feed intake and feed conversion ratio on days 21 and 42 of the experiment are presented in Table 2. From 1 to 21 days of age, feed intakes differed $(\mathrm{P}<0.01)$ between treatments. The intake of the birds fed the diet containing the antibiotic was the highest and those 
consuming the diet containing $72 \mathrm{mg} \mathrm{EOC} / \mathrm{kg}$ the lowest. However, there were no differences $(\mathrm{P}>0.05)$ in intake between the treatments over the 42 day period. From days 1 to 21 and 1 to 42 feed conversion ratios were significantly improved by the supplementation of the EOC at levels of 48 and $72 \mathrm{mg} / \mathrm{kg}$ diet. At day 42 , supplementation of $48 \mathrm{mg}$ EOC $/ \mathrm{kg}$ improved feed conversion ratio by $12.3 \%$ compared to the negative control. However, the feed conversion ratios were similar over the 42-day experimental period for the birds receiving the control diet and the diets containing the antibiotic and the $24 \mathrm{mg} \mathrm{EOC} / \mathrm{kg}$.

The effects of supplementing the EOC and the antibiotic on body weight, carcass yield and mortality up to the 21 st and 42 nd days of the experiment are presented in Table 3 . There were significant effects of dietary treatments on body weights at 21 and 42 days and carcass yield at 42 days. Birds receiving the diets containing 24, 48 and $72 \mathrm{mg} \mathrm{EOC} / \mathrm{kg}$ had significantly higher body weights at day 21 compared to those fed the control and the diet containing the antibiotic. At 42 days of age, body weights differed $(\mathrm{P}<0.01)$ between treatments. The birds consuming the diet containing $48 \mathrm{mg} \mathrm{EOC} / \mathrm{kg}$ feed had on average a higher body weight $(13.7 \%)$ than those on the control diet. At day 42 there were no differences $(\mathrm{P}>0.05)$ between body weights of birds receiving the diet containing $24 \mathrm{mg} E O C / \mathrm{kg}$ and the negative control. The body weights of birds fed the diets containing 24 and $72 \mathrm{mg} \mathrm{EOC} / \mathrm{kg}$ were lower $(\mathrm{P}<0.01)$ than those of the birds on the diet containing $48 \mathrm{mg}$ EOC/ $\mathrm{kg}$. Carcass yields differed $(\mathrm{P}<0.01)$ between the treatments at day 42 . The birds consuming the diet containing $48 \mathrm{mg}$ EOC $/ \mathrm{kg}$ had a higher carcass yield (3.3\%) than the negative control. Significant differences were also found between $48 \mathrm{mg} \mathrm{EOC} / \mathrm{kg}$ and the other dietary treatments. Mortality was not significantly different between treatments.

Table 3 The effect of the inclusion of an essential oil combination (EOC) or an antibiotic (avilamycin) on body weight (g), carcass yield (\%) and mortality (\%) of broilers up to the age of 42 days

\begin{tabular}{ccccc}
\hline \multirow{2}{*}{ Treatments } & \multicolumn{2}{c}{$\begin{array}{c}\text { Body weight } \\
\text { G }\end{array}$} & $\begin{array}{c}\text { Carcass yield } \\
\%\end{array}$ & $\begin{array}{c}\text { Mortality } \\
\%\end{array}$ \\
\cline { 2 - 5 } Control & 21 days $^{*}$ & 42 days* & 42 days* & 42 days \\
\cline { 2 - 5 } & $521^{\mathrm{b}}$ & $1656^{\mathrm{d}}$ & $71.94^{\mathrm{d}}$ & 1.33 \\
$10 \mathrm{mg}$ avilamycin/kg & $513^{\mathrm{b}}$ & $1730^{\mathrm{c}}$ & $73.08^{\mathrm{cd}}$ & 2.00 \\
$24 \mathrm{mg} \mathrm{EOC} / \mathrm{kg}$ & $551^{\mathrm{a}}$ & $1655^{\mathrm{d}}$ & $72.08^{\mathrm{d}}$ & 2.67 \\
$48 \mathrm{mg} \mathrm{EOC} / \mathrm{kg}$ & $565^{\mathrm{a}}$ & $1884^{\mathrm{a}}$ & $75.21^{\mathrm{a}}$ & 2.00 \\
$72 \mathrm{mg} \mathrm{EOC} / \mathrm{kg}$ & $566^{\mathrm{a}}$ & $1785^{\mathrm{b}}$ & $73.81^{\mathrm{bc}}$ & 3.33 \\
Standard error & 6.24 & 16.69 & 0.44 & 1.03 \\
$\mathrm{P}$ & 0.0001 & 0.0001 & 0.0001 & 0.7091 \\
\hline
\end{tabular}

* Means within columns with different superscript differ at $\mathrm{P}<0.01$

The significant improved body weights and feed conversion ratios of birds fed the diets containing 48

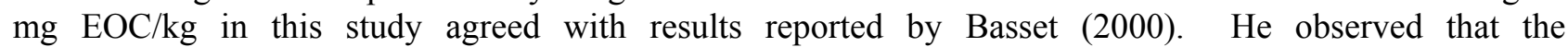
supplementation of oregano essential oil through the drinking water $(150 \mathrm{~mL} / 1000 \mathrm{~L})$ increased the body weight $(4 \%)$ and feed conversion ratio $(4 \%)$ of birds and reduced the period to slaughter by one day. Similarly, an improved performance in broilers was reported by Ather (2000) when using a poly herbal premix and liquid which contained five herbs. In agreement with these results, Hertrampf (2001) noted that by the age of three weeks the addition of essential oil isolated from oregano to the drinking water (300 $\mathrm{mL} / 1000 \mathrm{~L}$ ) improved the feed conversion ratio of broilers by $12.9 \%$. In another trial there were no differences in feed utilization between birds receiving the antibiotic, salinomycin, and those receiving an essential oil preparation (Hertrampf, 2001). However, more results are needed to clarify whether essential oils can match the effects of antibiotics as feed additives in broiler diets. The improved feed utilization with $48 \mathrm{mg} \mathrm{EOC} / \mathrm{kg}$ in our study could be due to a stimulating effect of essential oils on the digestion process, as reported by Langhout (2000) and Williams \& Losa (2001). In contrast to our results, Botsoglou et al. (2002) reported that the supplementation of essential oil (50 and $100 \mathrm{mg}$ oregano oil $/ \mathrm{kg}$ ) to broiler diet had no 
beneficial effect on broiler performance. Unfortunately, reports on the value of essential oils in broiler production are limited, though a number of studies did report the beneficial effects of essential oils as growth promoters in pigs (Tsinas et al., 1998). However, because of the banning of certain performance enhancing antibiotics in the EU, poultry producers are focusing on the potential of natural animal feed additives such as essential oils and combinations of these oils.

\section{Conclusions}

This study showed that the inclusion of $48 \mathrm{mg}$ EOC $/ \mathrm{kg}$ broiler diet significantly improved the body weight, feed conversion ratio and carcass yield of broilers after a growing period of 42 days. The supplementation of EOC in excess of $48 \mathrm{mg} / \mathrm{kg}$ had no additional beneficial effect on these production traits. The EOC could be considered as a potential growth promoter for broilers, because it meets the needs of producers for increased broiler performance and the consumers' demands that broiler production is conducted under environmentally friendly conditions. The EOC can be used cost effectively when comparing it costs with those of antibiotics and other commercially available products on the market. However, further and more complete evaluations are required to establish the effect of EOC in diets on the performance of broilers.

\section{Acknowledgements}

Financial and technical assistance of Poultry Research Institute of Erbeyli, Aydin and Herba Ltd. Co., Izmir-Turkey are gratefully acknowledged.

\section{References}

Anonymous, 1991. Animal feeds-Determination of metabolizable energy (chemical method). Turkish Standards Institute (TSE), Publ. No. 9610, 1-3.

Ather, M.A.M., 2000. Polyherbal additive proves effective against vertical transmission of IBD. World Poultry-Elsevier, 16(11), 50-52.

Bach Knudsen, K.E., 2001. Development of antibiotic resistance and options to replace antimicrobials in animal diets. Proc. Nutr. Soc. 60, 291-299.

Bassett, R., 2000. Oreganos positive impact on poultry production. World Poultry-Elsevier, 16(9), 31-34.

Botsoglou, N.A., Florou-Paner, P., Christaki, E., Fletouris, D.J. \& Spais, A.B., 2002. Effect of dietary oregano essential oil on performance of chickens and on iron-induced lipid oxidation of breast, thigh and abdominal fat tissues. Br. Poult. Sci. 43, 223-230.

Cowan, M.M., 1999. Plant products as antimicrobial agents. Clin. Microb. Rev. 12, 564-582.

Craig, W.J., 1999. Health-promoting properties of common herbs. Am. J. Clin.Nutr. 70 (suppl), 491S-499S.

Faleiro, M.L., Miguel, M.G., Ladeiro, F., Venancio, F., Taveres, R., Brito, J.C., Figueiredo, A.C., Barroso, J.G. \& Pedro, L.G., 2003. Antimicrobial activity of essential oils isolated from Portuguese endemic species of Thymus. Lett. Appl. Microbial. 36, 35-40.

Hertrampf, J.W., 2001. Alternative antibacterial performance promoters. Poult. Int. 40, 50-52.

Humphrey, B.D., Huang, N. \& Klasing, K.C., 2002. Rice expressing lactoferrin and lysozyme has antibioticlike properties when fed to chicks. J. Nutr. 132, 1214-1218.

Kamel, C., 2001. Tracing modes of action and the roles of plant extracts in non-ruminants. In: Recent advances in animal nutrition. Eds. Garnsworthy, P.C., \& Wiseman, J., Nottingham University Press, Nottingham. pp. 135-150.

Langhout, P., 2000. New additives for broiler chickens. World Poultry-Elsevier, 16(3), 22-27.

Lopez-Bote, L.J., Gray, J.I., Gomaa, E.A. \& Flegal, C.I., 1998. Effect of dietary administration of oil extracts from rosemary and sage on lipid oxidation in broiler meat. Br. Poult. Sci. 39, 235-240.

Marino, M., Bersani, C. \& Comi, G., 1999. Antimicrobial activity of the essential oils of Thymus vulgaris L. measured using a bioimpedometric method. J. Food Protec. 62, 1017-1023.

Mellor, S., 2000. Nutraceuticals-alternatives to antibiotics. World Poultry-Elsevier, 16(2), 30-33.

Naumann, C. \& Bassler, R., 1993. Die chemische Untersuchung von Futtermitteln. Methodenbuch, Band III. 3. Erg.,VDLUFA-Verlag, Darmstadt.

Osborn, E.M., 1943. On the occurrence of antibacterial substances in green plants. Br. J. Exp. Path. 25, 227231. 
Riebau, F.J.M., Berger, M.B. \& Yegen, O., 1995. Chemical composition and fungitoxic properties to phytopathogenic fungi of essential oils of selected aromatic plants growing wild in Turkey. J. Agric. Food Chem. 43, 2248-2252.

Riebau, F.J.M., Berger, M.B., Yegen, O. \& Cakır, C., 1997. Seasonal variations in the chemical compositions of essential oils of selected aromatic plants growing wild in Turkey. J. Agric. Food Chem. 45, 4821-4825.

SAS, 1985. Statistical Analysis Systems user's guide (5th ed.). SAS Institute Inc., Raleigh North Carolina.

Schwarz, S., Kehrenberg, C. \& Walsh, T.R., 2001. Use of antimicrobial agents in veterinary medicine and food animal production. Int. J. Antimicrob. Agents 17, 431-437.

Tsinas, A.C., Giannakopoulas, C.G., Papasteriades, A., Alexopoilos, C., Mavromatis, J. \& Kyriakis, S.C., 1998. Use of oreganum essential oils as growth promoter in pigs. In: Proc. $15^{\text {th }}$ IPVS Congr., July 1998. Birmingham, U.K. Vol 3, pp. 221.

Ultee, A., Bennik, H.J. \& Moezelaar, R., 2002. The phenolic hydroxyl group of carvacrol is essential for action against the food-borne pathogen, Bacillus cereus. Appl. Environ. Microbiol. 3, 1561-1568.

Wenk, C., 2000. Recent advances in animal feed additives such as metabolic modifiers, antimicrobial agents, probiotics, enzymes and highly available minerals. Review. Asian-Aus. J. Anim. Sci. 13, 86-95.

Williams, P. \& Losa, R., 2001. The use of essential oils and their compounds in poultry nutrition. World Poultry-Elsevier, 17(4), 14-15. 